\title{
Development of English Language Teaching Materials for the Economic Education Study Program
}

\author{
Wiwit Kurniawan ${ }^{1)}$,Saptina Retnawati ${ }^{2)}$, \\ ${ }^{1)}$ Universitas Pamulang \\ Email: dosen01536@unpam.ac.id \\ ${ }^{2)}$ Universitas Pamulang \\ Email: wiwitkurniawan1987@gmail.com
}

\begin{abstract}
The purpose of this study was to produce English language teaching materials for economic education study programs with a contextual approach. This research is a research and development ( $R$ and $D)$ which uses ADDIE development model. ADDIE stands for Analysis, Design, Development, Implementation, and Evaluation. The subjects of the study were students of Economic Education in class 02 PIEE 01 consisting of 30 students. The instruments used in this study are: (1) Instruments for measuring validity, including validation sheets; (2) Instruments for measuring practicality, including observer assessment sheets, student response sheets and learning implementation observation sheets; (3) Instruments for measuring effectiveness, including motivation questionnaires and learning achievement tests. The outcome of this research was learning devices in the form of module. The validation results showed that the lesson plan and module meet valid criteria with very good category. The results of field trials showed that the lesson plan and module meet practical and effective criteria. The practicality of the learning device developed reached a very good category based on observations of the implementation of learning and observer assessment, the module reached a good category based on student responses. Effectiveness reached an effective category based on the level of motivation and completeness of student learning. The percentage of the number of students who reached the high minimum category in the motivation questionnaire was $87.57 \%$ and the percentage of achievement in classical was $75 \%$. Thus, it can be concluded that the module is effective in terms of student learning motivation.
\end{abstract}

Keywords: Contextual Learning, Module, Economic. 


\section{INTRODUCTION}

The development of English originated from the simple language used by a few people in 1600, no less than four centuries later, English has become the most important language used in global communication today (Phillipson. 2012: 7). Nowadays, there are around 1.5 billion people in the world using English (Crystal: 2003: 6). In Indonesia, although English is not a formal language and is not widely used, it is considered the main foreign language and is taught in schools (Lauder, 2008: 11).

Seeing that English has an important position, in Indonesia English is taken from elementary school to college level. As discussed by Phillipson (2009: 6) English is widely used in science, technology, research, journals, books and education. Therefore, in universities, English is a medium for exchanging knowledge, as a gateway to access abundant sources of reference. English is used and translated in English for academic English and English for specific purposes. The concept of language renewal specifically designed to meet the needs of academics in accessing knowledge.

Although the role and function of English is very important, the mastery of English in Indonesia is still relatively low. The survey conducted by the English First English
Proficiency Index (EF EPI) in 2016 showed that Indonesia was ranked 32nd out of 72 countries (Valentina, 2016). In addition, the average TOEFL scores (Test of English as foreign Language) for Indonesians is still 470, where many scholarships require a score of 500 and 550 for foreign countries (Okozone.com, 2016). The data shows that in general Indonesian people have not mastered English well. Lack of mastery of English is also experienced by students of the Economic Education study program in University of Pamulang, Banten. From the initial observations and interviews with some students, the findings showed that they still felt difficulties in mastering English, as well as a lack of motivation in learning English. The value of the lecture data showed that at least $5 \%$ of students in the second semester of the 2017 school year who did not pass English language courses and there were $20 \%$ of students got C and below. This showed that there are still many students in the Economics Education study program who need an increase in mastery of English.

Although students get general English courses for all study programs, students are still having difficulty accessing knowledge sources both books and journals written in English. From the pre-observation, the researcher got the information that the teaching material for the economic 
education course had not been well designed. While this teaching material used still adopts an English module developed for the Secretary Study Program. Therefore, the instructor and students have difficulty in getting teaching materials that suit their needs.

From interviews with several Economics Education students, they gave a statement that they realized that English was very important in supporting the success of learning and career. However, the intrinsic motivation of students in learning English was still low. The inner awareness that learning English was not just a lecture and career demand has not been found in them. Therefore, learning motivation that is strong and consistent in mastering English is still lacking.

Learning English in the Economic Education Study Program is expected to support the achievements of the study program curriculum and graduate characteristics. The English material presented is expected to be able to support students to become researchers in the field of economic education and economic educators. Therefore, the English material prepared must adjust the context of the students where they are studying economics and trained to become an educator.

The locus of this study is the University of Pamulang (Unpam),
Economic Education Study Program. The university is used as a place of research because besides the affordability of researchers, Unpam has students from various backgrounds. In each department at UNPAM, including Economic Education, it has a vision to prepare students to be ready in the competitive world of work, so that every learning is oriented to work skills.

Teaching materials for ESP, especially in the field of economic education, are still rare. Teaching materials are available more in general English or English for business. In fact, the scientific field of economic education requires not only general English as a basis and business English, but English which includes various branches of economics and education which are taught in the department. Therefore this study focuses on developing English teaching materials for Economic Education. From these various backgrounds, the researcher proposed a study entitled "Development of English Language Teaching Materials for the Economic Education Study Program". 


\section{METHOD}

This type of research is development research. The development model used is the ADDIE model. ADDIE is a product development concept. ADDIE stands for Analysis, Design, Development, Implementation, and Evaluation (Branch. 2009: 17-18).

The first stage is the analysis phase including needs analysis, student analysis, and material analysis. Needs analysis aims to find out the problems faced in English courses. Student analysis is conducted to identify student characteristics according to their level of education according to the theory of human development. Material analysis was used to determine the material in the study based on the English syllabus of the Economics education study program. The second stage is the design stage in the form of preparing syllabus and teaching materials for English for Economic education study programs, as well as evaluation instruments. The third stage is the development stage, namely syllabus and teaching materials (draft 1) which have been prepared validated by experts and revised stage 1. Subsequently the implementation phase, namely product development, is tested in class and revised stage 2 if necessary. The last is the evaluation stage, which is to analyze the practicality and effectiveness of the teaching materials developed

The subjects in this study were students of the 2nd semester of Economic Education study program at the University of Pamulang 2017/2018 Academic Year. This research was conducted in April-June 2018.

The type of data in this study consists of quantitative and qualitative data. Quantitative data were obtained from the results of expert validation, lecturer assessment, student assessment, lecture implementation observations and English learning motivation questionnaires. Qualitative data is obtained from comments and suggestions about product development, as well as the results of quantitative data conversion. Data collection techniques are tests and non-tests.

The data collection instruments in this study consisted of (1) validation sheet, (2) lecturer assessment sheet, (3) student response sheet, (4) observation sheet, (5) student motivation learning questionnaire on English subjects. The data obtained is used to determine validity, practicality, effectiveness of the product being developed. This is in accordance with the quality criteria of the product results stated by Nieveen. Qualitative data in the form of comments and suggestions were analyzed qualitatively, then used as input to revise the products developed. 
Quantitative data in the form of Likert scale with 5 assessment categories are converted into qualitative data with formula references adapted from Widoyoko (2009: 238).

Tabel 1. Data Conversion Criteria

\begin{tabular}{cc}
\hline Interval Score & Category \\
\hline$X>\bar{X}_{i}+1,8$ Sbi & Excellent \\
$\bar{X}_{i}+0,6 S b i<X \leq \bar{X}_{i}+1,8$ & Very \\
$S b i$ & good \\
$\bar{X}_{i}-0,6 S b i<X \leq \bar{X}_{i}+0,6$ & Good \\
$S b i$ & \\
$\bar{X}_{i}-1,8 S b i<X \leq \bar{X}_{i}-0,6$ & Average \\
$S b i$ & \\
$\mathrm{X} \leq \bar{X}_{i}-1,8 S b i$ & Poor \\
\hline
\end{tabular}

Information:

$\mathrm{X} \overline{\mathrm{i}}$ (ideal average) $=1 / 2$ (ideal maximum score + ideal minimum score)

Sbi $\quad=1 / 6 \quad$ (ideal

maximum score - ideal minimum score)

$\mathrm{X} \quad=$ empirical score

The data analysis technique of effectiveness is viewed from learning motivation by determining the percentage of students who reach the minimum high category. Teaching materials are said to be valid if the average expert rating is at least in the "good" category. Teaching materials are said to be practical if the lecturer evaluates, student responses, and the percentage of the implementation of lectures is minimal in the "good" category. Teaching materials are said to be effective in terms of student learning motivation if the questionnaire results state that the empirical score after the use of instructional materials developed (final questionnaire) is higher than the empirical score before the use of teaching materials (initial questionnaire) and at least $80 \%$ of students in the class have achieved high minimum category.

\section{FINDINGS AND DISCUSSION}

In this study, the stages to be carried out include Analysis, Design, Development, Implementation and Evaluation (ADDIE). At present, the stages that have been carried out are stages of Analysis, Design, Development, and Implementation. Following is the description of the stage.

\section{Initial Product Development Results}

In the ADDIE stage, product development begins with an analysis to determine what and how the product will be made. In this study, the draft module of English language teaching materials at an early stage was called draft 1 . The basis for the development of draft 1 was the analysis phase. The aspects that were explored in the analysis phase were needs analysis, analysis of student characteristics and material analysis. Next is the translation in the analysis phase. 
Phase Analysis (analysis)

To develop an English language module that suits the students of the Economic Education study program, an analysis has been carried out by observation and interview. This analysis reveals how the conditions and learning needs of students, the characteristics of students and the material used in learning.

\section{Results of Need Analysis}

Based on the results of observations and interviews following the results of a needs analysis on commercial English learning:

a) Learning activities are dominated by the method of lecturing and work assignments. Students are asked to read the module and listen to the explanation from the lecturer. Occasionally the lecturer asks questions to students to know the understanding of the material.

b) Most students who take classes in English Commerce are less active in learning. Although the lecturer has given a question, it does not provide a stimulus for students to discuss in class.

c) The teaching material used is a module developed by the teaching team of the University of Pamulang ..

d) Learning outcomes are still low. This is conveyed by lecturers who have examined the results of student assignments.
The lecturers stated that the teaching materials available were not attractive in appearance or content. This makes students feel bored and do not understand learning well.

\section{Results of Student Analysis}

From the results of the analysis of student characteristics carried out by observation methods are summarized as follows:

a) Students are less motivated in learning.

b) Students feel saturated with material.

c) Students are more interested in listening to material related to their profession.

d) Students are more enthusiastic to learn material that is felt useful in their lives.

\section{Development Stage (Development)}

Modules from the design stage are in the form of module design so that in the development stage a module will be developed in accordance with the design that has been implemented. The revised results of the validator are analyzed and reflected to develop the module that will be implemented. The results of the development phase are as follows:

1. Module Development

From the design results, an English language module for Economic Education Study Program with the 
foundation of CTL and ESP will be oriented towards student motivation.

Following is the design of the module:

\begin{tabular}{llll}
$\begin{array}{l}\text { Theoretical } \\
\text { Concept }\end{array}$ & Module Section & Description & $\begin{array}{l}\text { Motivation } \\
\text { Orientation }\end{array}$ \\
\hline $\begin{array}{l}\text { ESP and CTL } \\
\text { concept }\end{array}$ & Snap Shot & $\begin{array}{l}\text { Providing unique } \\
\text { facts in the fields } \\
\text { of economics and } \\
\text { business, as an } \\
\text { icebreaker and } \\
\text { adding }\end{array}$ & $\begin{array}{l}\text { Give motivation by } \\
\text { describing unique }\end{array}$ \\
& & information & \\
& &
\end{tabular}

Authentic

Core Activity

Linking

Learning

Materials to

the Student

Environment.

Describe the material in detail

with a focus on

skills. The

material

promoted uses

authentic

material.

Give motivation by

presenting authentic

material related to

the working

environment, so that it is meaningful and effective.

Give a brief

review of

grammar to

improve the

Students are

Flash Grammar

effectiveness of

language

Give motivation by

presenting grammar

material with

able to

understand

what, why and

.

interesting and short

displays.

how material

is beneficial to

life

Evaluation

Provide

opportunities for

students to assess

Provide questions themselves so that

and exercises to they are motivated to measure students' learn more actively

abilities. 


\section{CONCLUSION}

The development of English language modules as teach in materials for students in the Economic Education Study Program requires not only the depth of the material but the suitability of the material theme context. In this study, the basic things that need to be considered to achieve validity, effectiveness and practicality are the attractiveness of the module display, the suitability of English material, the ease of reading and the compatibility of material themes with what students want.

From the research that has been done, it can be concluded that the modules developed with the ADDIE model can be said to be valid, practical and effective. The validity analysis of the module is seen from the aspect of content / material and the presentation is in a very good category. In practicality analysis, it consists of three components, namely analysis (1) assessment of lecturers, (2) response of students, and (3) observation of implementation of learning. The three components of practicality are very well categorized. For module effectiveness, it can be seen from student achievement and motivation. The percentage of motivation achievement in classical is $75 \%$. While for the average score of the learning achievement test, it is above the completeness criteria and all students meet the criteria for completion. This means that the learning device is effective in terms of student learning motivation and achievement.

Future suggestions for other researchers are to develop English language modules specifically for education. Students need special books that are more in-depth as a reference for using English in the context of teaching. The output of graduates from teacher training programs is the teaching profession. Therefore, English language education in all teacher training departments must contribute to the teacher's aspect 


\section{REFERENCES}

Basturkmen, H. (2010). Developing courses in English for specific purposes. New York: Springer.

Branch, R. M. (2009). Instructional design: The ADDIE approach (Vol. 722). New York: Springer Science \& Business Media.

Crystal, D. (2003). English as a Global Language. Cambridge: Cambridge University Press

Hudson, C. C., \& Whisler, V. R. (2007). Contextual Teaching and Learning for practitioners. Studies in the Education of Adults and Carrer Education GA 31602 USA. vol 3 no 1. 54,58 .

Phillipson, R. (2012). Linguistic imperialism continued. Oxford: Oxford University Press.

Iqdami, M. N. (2011). The Implementation of Contextual Teaching And Learning (CTL) In English Lesson Plans for The First Year Students of High School (A Comparative Study on English Lesson Plans Used at MAPK Surakarta and SMA Assalam Surakarta). Tesis
S2 di STAIN Salatiga tahun 2011

Johnson, E. B. (2002). Contextual teaching and learning: What it is and why it's here to stay. California: Corwin Press.

Lauder, A. (2010). The status and function of English in Indonesia: A review of key factors. Makara HubsAsia, 8(3). pp. 9-20

Okezone. (2016, Oktober 03).

Retrieved Juni 10, 2017, from Okezone.com:

http://news.okezone.com/r ead/2016/03/10/65/133217

6/rata-rata-skor-toefl-diindonesia-di-bawah-500

Pennycook, A. (2010). English and globalization. In J. S. Janet Maybin, The Routledge companion to English language studies (pp. 113121). New York: Routledge.

Purwati, A. D. (2016). Developing English Learning Materials for the 3rd Semester Students of Informatics Engineering Education Program at Yogyakarta State University. Skripsi S1 di Universitas Negeri Yogyakarta tahun 2016 
Pribadi, B. A. (2009). Model desain sistem pembelajaran. Jakarta: Dian Rakyat

Swerdlik, M. E., \& Cohen, R. J. (2005). Psychological testing and assessment: An introduction to tests and measurement. New York: McGraw Hill Education

Valentina, J. (2016, December 15). Youth News: The Jakarta Post. Retrieved Juni 10, 2017, from The Jakarta Post: http://www.thejakartapost. com/youth/2016/12/15/ind onesia-ranks-32nd-inenglish-proficiencyindex.html

Widoyoko, E. P. (2009). Evaluasi Program Pendidikan. Yogyakarta: Pustaka Belajar.

Winkel, W. S. (2005). Belajar dan Pembelajaran dalam Pencapaian Prestasi. Jakarta: Sagung. 